\title{
PSYCHOLOGICAL FACTORS OF PROFESSIONAL STRESS OF EMPLOYEES OF THE NATIONAL POLICE OF UKRAINE
}

Kisil Z. R.

\author{
Stress is the flavor and taste of life, it can only \\ be avoided by someone who does not do anything... \\ G. Selie
}

\section{INTRODUCTION}

According to Article 2 of the Law of Ukraine "On National Police", the National Police of Ukraine performs a number of tasks in providing police services in the following areas: 1) ensuring public safety and order; 2) protection of human rights and freedoms, as well as the interests of society and the state; 3 ) crime counteraction; 4) provision of assistance services to persons who, for personal, economic, social reasons or as a result of emergencies, need such assistance in the limits specified by law, which in turn determine the specific nature of their professional activities. Taking into account the importance of the tasks entrusted to the National Police, the probability of admittance to law enforcement activity psychologically unprepared police officers is greatly threatening as it leads to errors in professional activity, errors in risky and stressful situations.

The activities of the National Police staff of Ukraine are mostly carried out in extremely difficult conditions, namely: an unstable political and economic situation in the state, an aggressive environment of communication, stressfulness and riskiness, a constant shortage of time, a high level of personal responsibility for the results of their activity.

The realities of the present give us reasons to assert that the problem of experiencing stress is extremely relevant, and the ability to overcome it and cope with it is transformed into a frontal problem. Thus, the lack of psycho-emotional preparedness of the police officers leads to poor quality of performance of operative duties, traumas and injuries, and sometimes to death. All the above mentioned 
circumstances determine the relevance and need for the study of determinants of stress in the professional activities of the staff of the National Police of Ukraine.

The thorough scientific and theoretical basis in the study of stress, its determinants, in particular among the police, the ways of its prevention are presented in the the scientific works of foreign and Ukrainian scientists - J. Bright, J. Greenberg, R. Lazarus, G. Selye, J. Aleksandrovsky, G. Balla, V. Bodrov, O. Bondarenko, N. Vodopianov, T. Zaichikov, G. Lozhkin, V. Klymenko, M. Korolchuk, V. Krainyuk, O. Laktionov, A. Maklakov, I. Malkina-Pykha, O. Malkhazov, S. Maksymenko, O. Markovets, O. Samoilov, O. Sannikov, N. Perogonchuk, V. Pankovets, Y. Pluzhnyk, N. Tarabrin, O. Timchenko, O. Rakovchen. Scientific researches of O. Hanushkin, M. Dyachenko, L. Nersesyan, V. Pushkin, O. Safin, M.Tomchuk are devoted to the problems of the systemic-structural approach to the study of psychological readiness for the activity. The generalized conclusions, positions of scientific works of such well-known scientists in the field of psychology as Yu. Alexandrovsky, H. Nikiforov, V. Maryshchuk, N. Tarabrin, N. Bacherykov, N. Vorontsov, P. Petryk, V. Molyako, O. Morozov, L. Kryzhanivska, V. Klymenko, M. Savchyn, S. Yakovenko were taken into account in the disclosure of the effects of stress factors, which in future can lead to maladaptive behavior and psychosomatic disorders and suicides.

The purpose of the article is to determine the psychological factors of the emergence of professional stress among employees of the National Police of Ukraine.

\section{Tasks:}

1. To characterize the essence of professional stress as a scientific category.

2. To analyze the peculiarities of the manifestation of professional stress among the employees of the National Police of Ukraine in stressful and risky situations during professional activity and its psychological consequences.

3. To analyze the specifics of the activities of the National Police staff and its tension.

4. To conduct an empirical study of psychological determinants of stress among employees of the National Police of Ukraine. 


\section{Methods of research}

The methodological basis for the study are philosophical and ideological approaches in the context of psychological science (anthropological, humanistic, synergetic), general scientific methods (comprehensiveness, objectivity, complexity, specificity, etc.) and principles of psychology (determinism, unity of consciousness and activity, development, activity).

In addition, historical and comparative methods were used to trace the development process and the state of scientific development of stress issues. Systemic, structurally functional, civilizational, socio-cultural methods were used to identify the determinants of stress in the activities of the National Police staff in Ukraine as in a specific professional environment, endowed with the qualities of both open and closed functionally oriented system that is clearly hierarchical (structured) and at the same time corporate-integral (monolithic). The application of the logical-semantic and hermeneutic methods made it possible to clarify the content of the conceptual apparatus of the study in a sign socionormative context. The sociological-genetic method served as an analysis of the stress factors in the daily activities of the staff of the National Police of Ukraine. Formally logical method contributed to the justification of the psychosomatic status of a policeman. Experimentalgenetic method and active modeling method were used during the empirical study of the influence of stress factors on the professional activity of police officers, on the basis of which it was possible to recreate the special conditions of the occurrence and formation of the psychological functions of the modern Ukrainian policeman in the ontogenesis.

To identify stress factors in the professional activities of National Police officers, a number of proven research methods have been applied, namely the Holmes-Reich Scale of Stress Resilience and Social Adaptation, the Boston Stress Test and the Integrated Assessment of Stress (Y. Shcherbatykh), questionnaires: "The level of professional stress "(K. Vayman); "Inventory of symptoms of stress" (T. Ivanchenko); "Differentiated assessment of conditions of reduced working capacity" (G. Leonova, B. Velychkovskyi); methods of "Losses and Achievements of Personal Resources" (N. Vodopianova, M. Stein), "Coping Strategies in Stress Situations" (S. Norman, D. Andler, 
D. James, M. Parker (adaptation of T. Kryukova), author's questionnaire - to study the needs of police for anti-stress programs.

150 students of the Faculty № 4 of Lviv State University of Internal Affairs participated in the experiment (42 students presented the Main Department of National police in Lviv region, 18 respondents presented Vinnytsya oblast, 14 - Volyn oblast, 10 - Transcarpathian region, 26 Ivano-Frankivsk region, 17 - Chernivtsi region, 23 persons -Ternopil region). 120 persons were males, 30 were females.

\section{Results and discussions}

The concept of "stress" was first introduced in 1939 in the scientific terminology by G. Selye. He considered it as "... a non-specific response of the body to any demand that it poses." ${ }^{1}$ Despite the long history of permanent attempts to study the phenomenon of "stress", there is still misunderstanding about its concept among scholars. The analysis of scientific inquiries gives grounds to state that the term "stress" is used in the following meanings: "mental stress", "nervous-psychic tension", "psycho-emotional intensity"2; "emotional stress"3, "potential threat"4; the individual's reaction to the situation ${ }^{5}$; the quality of a situation that does not depend on the individual's attitude toward it ${ }^{6}$; a condition that creates an obstacle that is an internal reaction to stressors ${ }^{7}$.

Among modern scholars, the notion of "stress" is defined as: an external stimulus or an event that causes personal pressure or irritation ${ }^{8}$; a subjective reaction that reproduces the internal psycho-emotional state of the tension, which is interpreted as emotions, defensive reactions and coping processes that an individual experiences ${ }^{9}$; physical reaction of an

\footnotetext{
${ }^{1}$ Селье Г. Стресс без дистресса. М.: Прогресс, 2005. 253 с.

${ }^{2}$ Апчел В.Я. Стресс и стрессоустойчивость человека / В.Я. Апчел, В.Н. Цыган.

3 Овчинников Б.В., Колчев А.И. Профессиональный стресс и здоровье // Психология профессионального здоровья. СПб. : Речь, 2006. С. 204-213.

${ }^{4}$ Abouserie R. Stress, coping strategies, and job satisfaction in university academic staff. Educational Psychology. 1996. № 16. P. 49-56.

${ }_{6}^{5}$ Mechanic D. Students under Stress. New York: Free Press, 1962. P. 117.

6 Basowitz H., Persky H., Korchin. Sh., Grinker R. Anxiety and Stress: An Interdiscipplinary Study of a Life Situation. New York: McGrow-Hill, 1955. P. 203-243.

${ }^{7}$ Selye H. The stress of life. New York: McGrow-Hill, 1956. P. 81-94.

8 Бодров В.А. Информационный стресс : учебное пособие. М.: ПЕРСЭ, 2000. $352 \mathrm{c}$.

Тімченко О.В. Синдром посттравматичних стресових порушень: концептуалізація, діагностика, корекція та прогнозування : монографія. Харків : Вид-во Ун-ту внутр. справ, 2000. 268 с.
} 
individual's body to a certain requirement or harmful influence ${ }^{10}$. Concerning the study of professional activity, B. Margolis, V. Croes and R. Cunn in their research "Labor stress: unregistered occupational danger" introduced the term "labor stress"11.

The essence of the concept of "stress" has changed considerably since its appearance, which is directly related to the expansion of the scope of its use and more thorough research of various aspects of the problem. Currently, the determinants of the emergence of "stress" include heterogeneous factors. Most scholars tend to believe that the basic determinants of stress include subjective factors - the subjective evaluation of factors as stressful ${ }^{12,13,14,15}$; individual psychological features of the personality (internal factors) ${ }^{16,17,18}$; psycho-physiological determinants of "stress" (sensory deprivation, excessive loads, state of fatigue, monotony, disturbances of the rhythm of sleep and vivacity); psychosocial determinants of stress (information isolation, information shock, disturbance of communication, prolonged loneliness, group isolation, loss of workplace, professional burnout, family problems, household problems, affiliation to a particular national or sexual minority) ${ }^{19,20}$.

A serious scientific and theoretical basis for the study of "professional stress" is the theory of "personal factor" ${ }^{21}$; "informational

${ }^{10}$ Рогачова Т.В., Залевський Г.В., Левицька Т.Е. Психологія екстремальних ситуацій і станів. Т.: Видавницький дом ТГУ. 2015. 276 с.

${ }_{11}$ Margolis B.L., Kroes, W.H., Quinn, R.P. Job stress: an anlisted occupational hazard. Journal of Occupational Medisine. 1974. No 6. P. 659-661.

${ }^{12}$ Кокс Т. Стресс / Т. Кокс. М., 1981. 216 с.

${ }_{13}^{13}$ Китаев-Смык Л.А. Психология стресса. М. : Знание. С. 340.

14 Бодров В.А. Информационный стресс : Учебное пособие для вузов. М.: ПЕРСЭ, 2000. $352 \mathrm{c}$.

15 Борневассер М. Стресс в условиях труда // Психические состояния. Хрестоматия. СПб.: Питер, 2000. С. 195-214.

16 Санникова О.П. Адаптивность личности : монография / О.П. Санникова, О.В. Кузнецова. О. : Изд. Н.П.Черкасов, 2009. 258 с.

${ }_{18}^{17}$ Васильев В.Н. Здоровье и стресс. М.: Знание, 1991. 160 с.

18 Пономаренко В.А. Пора прекратить избиение «человеческого фактора». Вестник МНАПЧАК. 2008. №1 (27).

19 Лебедев В.И. Личность в экстремальных условиях. М. : Политиздат, 1989. $304 \mathrm{c}$.

${ }_{20}^{20}$ Гримак Л.П. Резервы человеческой психологии. М.: Политиздат, 1987. $231 \mathrm{c.}$

21 Синдром “професійного вигорання" та професійна кар'єра працівників освітніх організацій: гендерні аспекти : навч. посіб. для студ. вищ. навч. закл. та слухачів ін-тів післядиплом. освіти / за наук. ред. С.Д. Максименка, Л.М. Карамушки, Т.В. Зайчикової. К.: Міленіум, 2004. 264 с. 
stress"22 "variations of state activation (VSAT); "personal control"23; and "Functional Stress Model"24, "A Model of Professional Stress"25.

Nowadays, scientists pay special attention to the conditions of professional activity, as the influence of stress factors that arise in professional activities cannot be diminished. A number of scholars tend to believe that personality's stress that arises in the process of performing direct professional duties should be regarded as a characterological form of stress $^{26}$. During the study of the negative influence of stress factors while performing professional functions and their negative consequences in scientific terminology the term "professional stress" was introduced ${ }^{27}$.

Recently, scientific research has been intensified on the study of the influence of stress factors on the personality of the law enforcement officer in the process of fulfilling their tasks ${ }^{28,29,30,31}$. Professional activity of police officers is always accompanied by stress factors, high complexity and responsibility. Among the number of stress factors that adversely affect the psycho-emotional state of the police, scientists highlight the following: the seizure of hostages by terrorists; confrontation with an armed criminal; detaining a dangerous perpetrator; getting injured while performing professional duties; constant interaction

${ }^{22}$ Averill, J. R. (2005). Emotions as mediators and as products of creative activity. In J. Kaufman \& J. Baer (Eds.), Creativity across domains: Faces of the muse. (pp. 225-243). Mahwah, NJ: Erlbaum.

${ }^{23}$ Brajt Dzh. Stress: Teorii, issledovanija, mify. SPb.: Evroznak, 2003. 352 s.

${ }^{24}$ Karasek R.A. Job demands, job decision latitude, and mental strain: Implications for job redesign. Admin. Sci. Q. 1979. Vol. 24. P. 285-307.

25 Хокки Р., Хамильтон П. Когнитивные паттерны стрессовых состояний // Психология труда и организационная психология: современное состояние и перспективы развития: Хрестоматия. М.: Радикс, 1995. С. 225-242.

${ }^{26}$ Furnham A. Personality of work. London: Routledge, 1992. 354 p.

27 Ross K., Altmaier E. A. Handbook of Counseling for Street at Work. London: Sage Publication, 1999. 108 p.

28 Тімченко О.В. Професійний стрес працівників органів внутрішніх справ України (концептуалізація, прогнозування, діагностика та корекція) : автореф. дис... д-ра психол. наук: 19.00.06. Х.: НУВС, 2003. 35 с.

29 Кісіль 3.Р. Юридико-психологічні засади запобігання професійній деформації працівників правоохоронних органів : монографія. Львів: Львівський державний університет внутрішніх справ, 2016. 848 с.

30 Осьодло В.I. Особистісні чинники подолання стресових ситуацій в особливих умовах / В.І. Осьодло // Проблеми екстремальної та кризової психології. 2013. Вип. 14(1). С. 242-252.

31 Барко В.I. Психологія управління персоналом органів внутрішніх справ (проактивний підхід) : монографія. К.: Ніка-Центр, 2003. 448 с. 
with the criminal world; high level of responsibility for a decisions taken in conditions of information uncertainty; stressfulness and riskiness of performed functions; tension in communication in the field of professional activity; the use of measures of physical coercion, or firearms for killing, and so on. According to Professor V. Lieftierov, "... an employee who used weapons to defeat inevitably undergoes certain successive phases of the emotional consequences of a traumatic event. Each employee differently experiences posttraumatic phases and psychological reactions inherent to them, depending on the individual psychological characteristics, the level of adaptability and experience, the age of the worker, the target of shooting (the reputation of the suspect), the degree of risk and the danger of a shootout (how bloody it was), the legal and administrative consequences of what has happened. In addition, the awareness of the police officer of possible legal, social and psychological consequences after the use of firearms creates psychological "barriers" to ensuring the reliability of his actions in special conditions" ${ }^{32}$.

Consequently, the study of the state of stress in professional activities suggests that phenomenologically, and in terms of the peculiarities of regulation mechanisms, the occupational stress of the National Police staff of Ukraine is a specific type of stress and can be defined as a multidimensional phenomenon of physiological and psychological reactions of the law enforcement officer to a difficult official situation.

The generalization of the provisions of the modern doctrine of psychological and professional stress determines the feasibility of analyzing the mechanisms of stress development among the employees of the National Police of Ukraine. Thus, at the level of macroanalysis of professional stress one can obtain a holistic description of the risk factors of operative and official activity in terms of causal relationships. An analysis at the level of intermediate stress mediation will allow taking into account the individual psychological features of the employee of the National Police of Ukraine and his personal experience in overcoming stressful situations. The level of microanalysis, reflecting

32 Лєфтєров В.О. Теоретичний аналіз стресогенних чинників професійної діяльності працівників міліції. Вісник Начіональної академії оборони. № 4(17). 2010. C. $167-171$. 
the psychological mechanisms of adaptation of a specific worker of the National Police of Ukraine to stressful conditions, will allow predicting the effectiveness of the implementation of specific operational and official tasks.

The analysis of scientific developments in this area gives grounds to summarize that the model of professional stress of National Police staff of Ukraine can consist of three blocks: external stress factors; internal stress factors; physiological and psychological manifestations of professional stress.

The research of psychological factors of stress among employees of the National Police of Ukraine was conducted in two stages. At the first stage a theoretical and methodological analysis of the problem was conducted, and at the second stage an empirical study was carried out, which provided an opportunity to analyze the peculiarities of the course of professional stress among employees of the National Police of Ukraine and to identify the psychological determinants of its occurrence.

At the first stage of the study, an assessment of the level of professional stress among employees of the National Police of Ukraine was made. For the purpose of studying the emotional, behavioral and physiological state and the corresponding symptoms among the employees of the National Police of Ukraine, the methodology of "Comprehensive Assessment of Stress" (Y. Shcherbatykh) was used, which consists of 26 questions concerning individual work and life situations. After conducting a survey by Y. Shcherbatykh's method, almost half of respondents have shown: moderate stress (41\%), expressed stress (23\%), severe stress (2\%), and stress is absent among $34 \%$ of respondents (see Diagram 1).

In order to determine the dominant parameters and characteristics of professional stress and the peculiarities of police officers' responding to it, a factor analysis was conducted. As a result of its fulfillment, three latent factors that have a significant impact on the personality of the policeman and his response to stress were established (see Diagram 2).

The psychological essence of the first factor is based on the fact that the following determinants influence the development of professional stress among employees of the National Police of Ukraine: personal adaptive index (0.93), neuropsychiatric stability (0.90), anxiety (0.78), communicative abilities $(0,76)$, moral normativity $(0,68)$. 


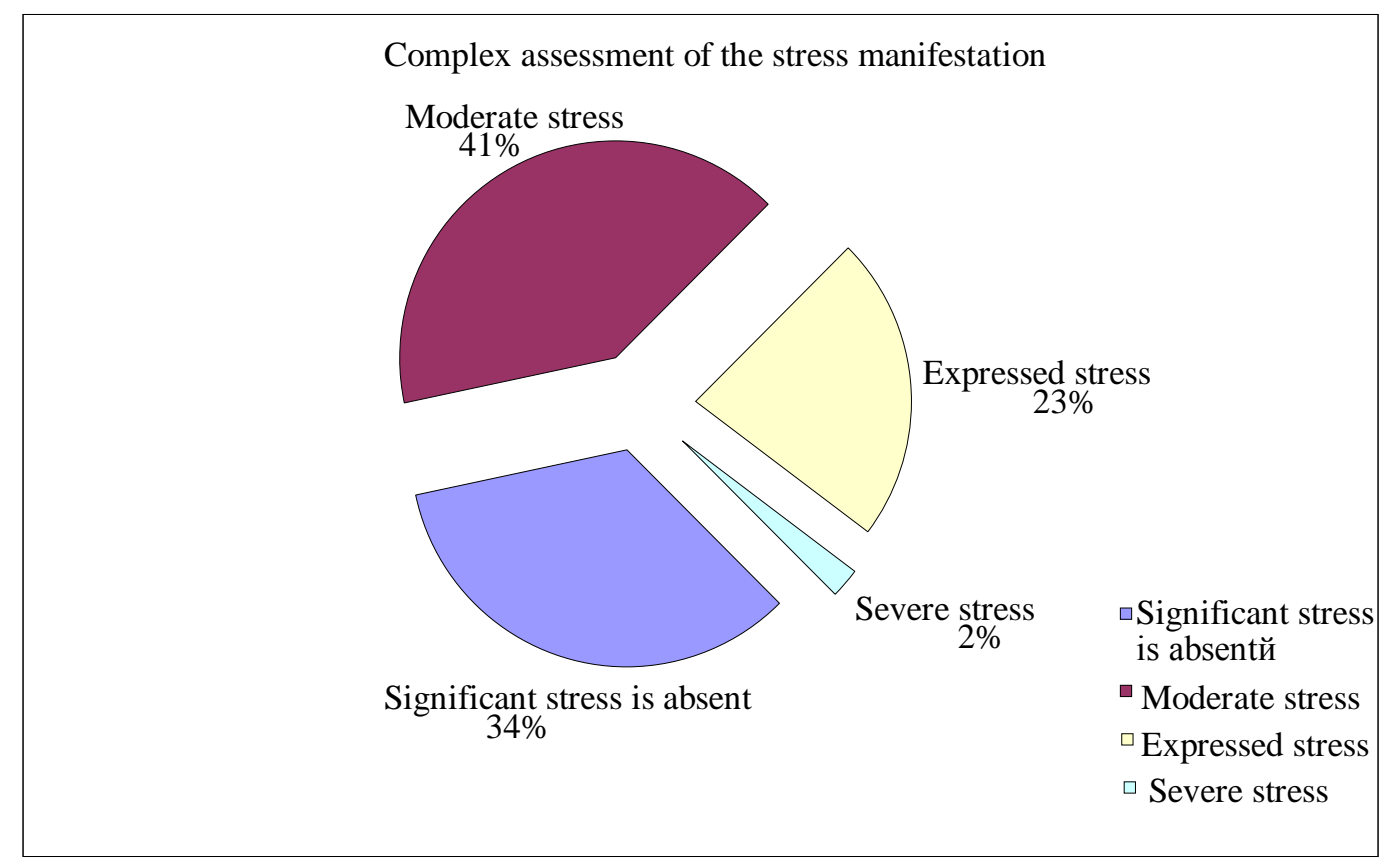

\section{Diagram 1. Distribution of respondents according to the methodology of Y. Shcherbatykh}

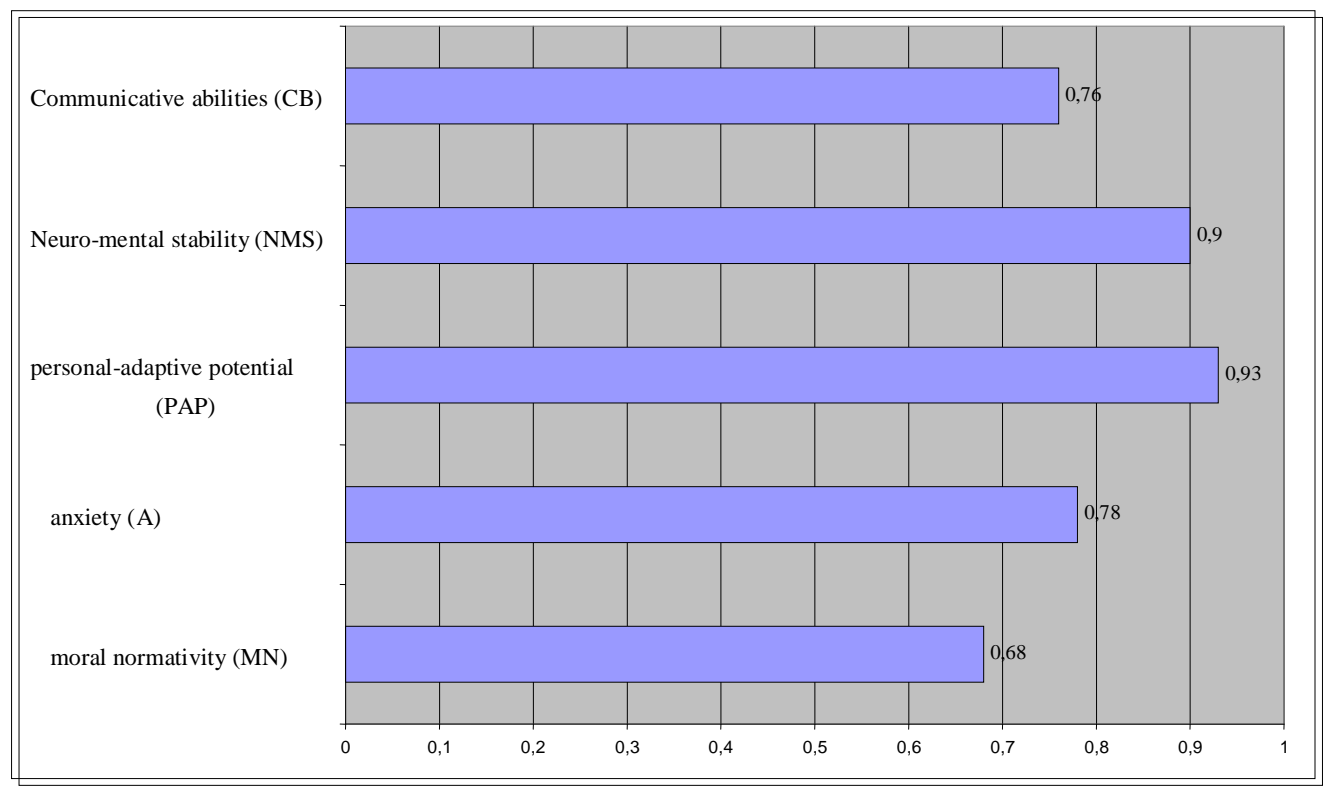

\section{Diagram 2. Image of the first factor of "Distressing-adaptive individual differences in reacting"}

The high level of "personal adaptive potential" indicator is the evidence that respondents have a high motivational orientation towards success in their professional activities, ability to adapt to changes in socio-political life, satisfaction with the chosen profession, etc. The high 
level of neuro-mental stability indicator obtained in the process of research is the evidence that in the daily activities police officers are characterized by the sequence of actions and the purposefulness of behavior. The respondents' anxiety is reflected in the fact that their activities are accompanied with a high level of complexity of the assigned tasks and responsibility for the results. The ability of police officers to use three main functions of communication, namely: communicative, interactive, and perceptive, is shown by the indicator of "communicative abilities". The police self-assessment of their actions only in the legal field must coincide with their personal views of a moral character. Knowledge of the norms of the current legislation and its implementation into practical activities are extremely important for lawenforcers, as this is a prerequisite for the moral responsibility of the police officer's personality both to the society and to his own conscience. Only perceived legal rules by the police officers acquire the importance of personal values and the importance of moral standards.

The second factor, "Peculiarities of individual stress differences", obtained as a result of factor analysis, allowed to distinguish factors influencing the development of stress among employees of the National Police of Ukraine (see Diagram 3).

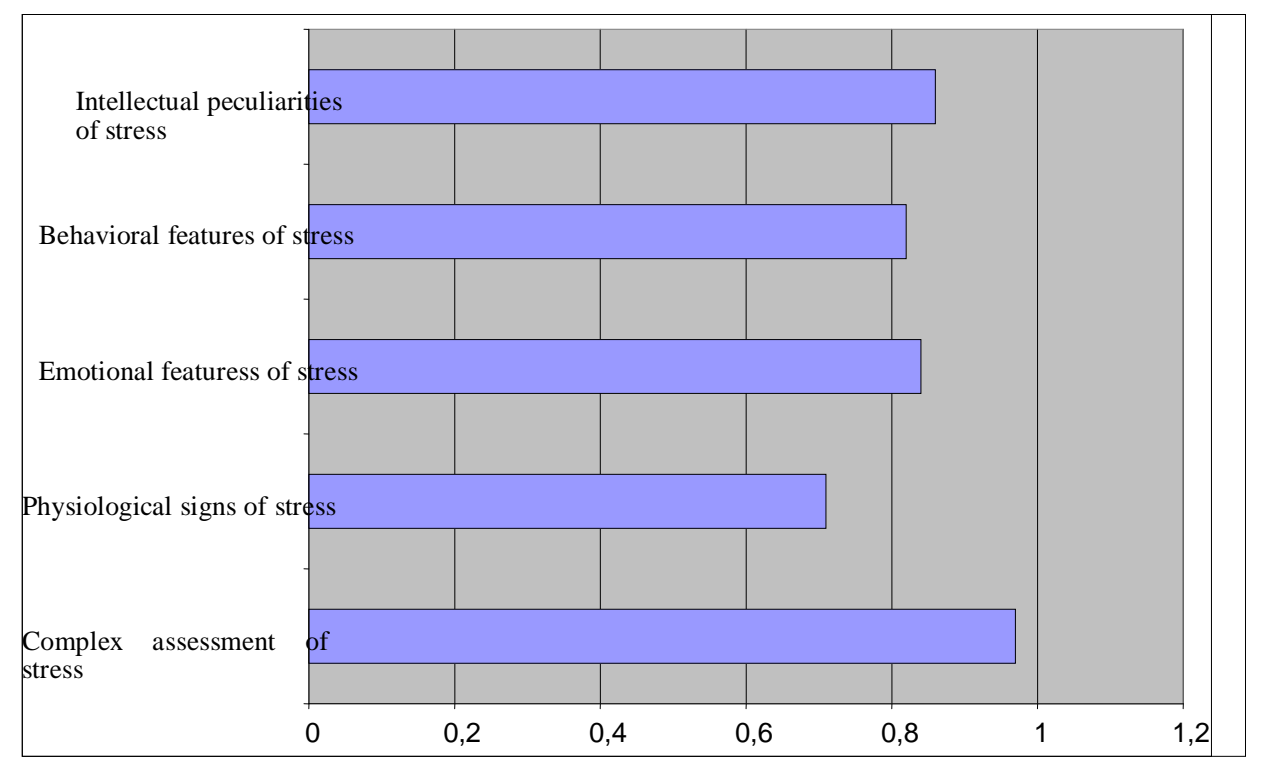

Diagram 3. Image of the second factor "Peculiarities of the individual differences in stress manifestation" 
A significant indicator of physiological stress $(0.71)$ is caused by the specifics of the work of the National Police staff of Ukraine, since their professional activity is always accompanied with physical overload of the body. Emotional stress (0.84) in the professional activities of the employees of the National Police of Ukraine occurs if there is a threat, in risky situations, in the period of long anticipation of possible complications of the operative circumstances. The activity of the police officers often occurs in conditions of information uncertainty, complex, fast variable and hardly predicted situations. The need to choose a coping strategy (conscious effort to solve problems and attempts to master, minimize or level them) in stressful situations leads to the occurrence of information stress (0.86). Constant manifestations of stress during work by police officers can cause both a mobilizing and disruptive effect, which leads to a general decrease in the adequacy of the functioning of the mental sphere, further to the emergence of behavioral features of stress (0.86).

The third factor, "Peculiarities of Personality's Productivity", consists of two diagnostic criteria (see Diagram 4).

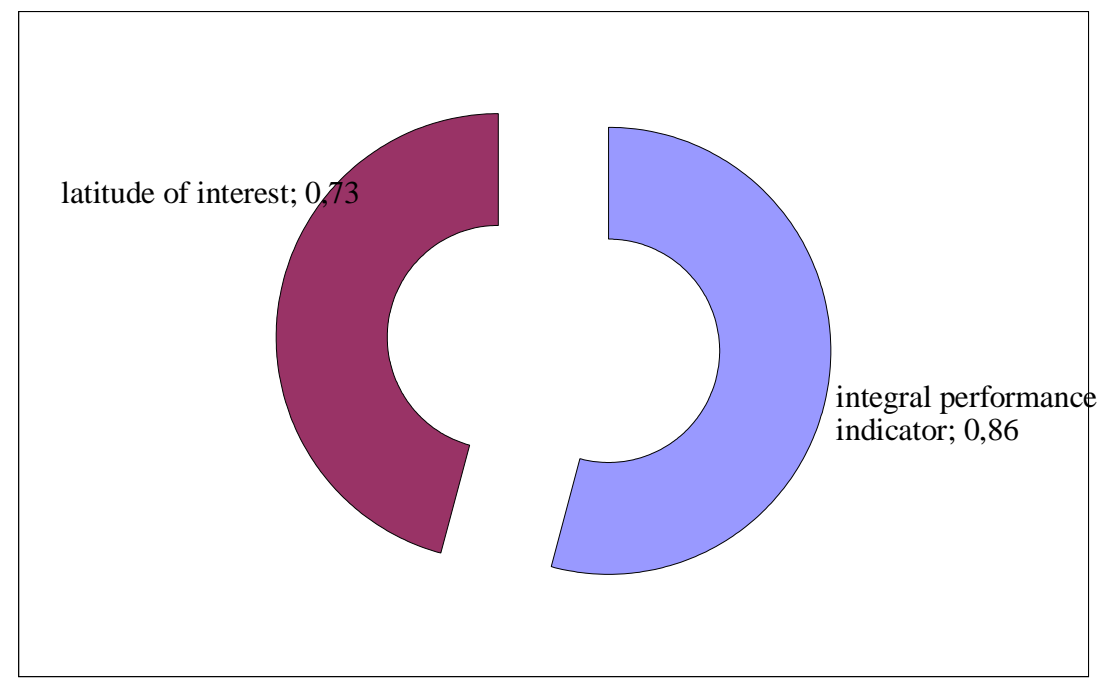

\section{Diagram 4. Image of the third factor "Features of personality's performance"}

The psychological essence of the "Latitude of Interest" factor (0.73) is based on the fact that the general intellectual development, the latitude of interests, and the desire of the employee of the National Police of 
Ukraine to study throughout his life directly influence the dynamics of stress development.

Applying the methodology of expert assessments of the success of the professional activity of the police officer, it was established that the professional success of respondents is significantly influenced by: "Professionalism" - 5,7 \pm 0,06 points; "Intelligence" - 4,9 $\pm 0,08$ points; "Leadership" $-5,4 \pm 0,07$ points; "Self-control" $-5.4 \pm 0.10$ points. (see Table 1). All data are within the average values of a seven-point evaluation scale.

Table 1

Characteristics of factors that determine the success of professional activities of the National Police employees

\begin{tabular}{|c|c|c|c|c|}
\hline Indicators & Professionalism & Intelligence & Leadership & Self-control \\
\hline $\mathrm{M}$ & 5,7 & 4,9 & 5,4 & 5,4 \\
\hline$\sigma$ & 0,6 & 0,9 & 0,7 & 1,0 \\
\hline $\mathrm{m} \pm$ & 0,06 & 0,08 & 0,07 & 0,10 \\
\hline
\end{tabular}

Application of "Self-Assessment of Stress Tolerance" method (S. Couchen, G. Williamson) makes it possible to state that the level of correlative relations, expressed by respondents both by separate connections and by the correlation coefficients, is 0.72 .

The noteworthy stage of the research was aimed at elucidating the needs of the employees of the National Police of Ukraine for anti-stress programs. During the study, $75.9 \%$ of the respondents indicated that they did not have such programs in their units, which is evidence of insufficient attention to prevention and overcoming the phenomenon of occupational stress. Half of the respondents pointed to the urgent need for such anti-stress programs.

On the basis of the conducted research it can be stated that the prevention and overcoming of professional stress in the work of the police requires special psychological conditions, namely: 1) the mastery of knowledge about the nature and determinants of the emergence of professional stress; 2) mastering methods for identifying professional stress; 3) studying the mechanism of prevention and overcoming professional stress. 


\section{CONCLUSIONS}

1. Professional stress among employees of the National Police of Ukraine is generated by factors that are most diverse in nature; one of the dominant among them is the specifics of the conditions of the police officer's work.

2. The professional activities of the staff of the National Police of Ukraine are conditioned by the following stress factors: the seizure of hostages by terrorists; confrontation with an armed criminal; detaining a dangerous perpetrator; getting injured while performing professional duties; constant interaction with the criminal world; high level of responsibility for a decisions taken in conditions of information uncertainty; stressfulness and riskiness of performed duties; tension in communication in the field of professional activity; the use of measures of physical coercion, or firearms for killing.

3. It is stated that psychological tension leads to the emergence of stressful situations. Three basic approaches to the analysis of professional stress have been substantiated: 1) since it is caused by the discrepancy (or incompatibility) with the requirements of the working conditions and the individual resources of the employee, it is important to identify the imbalance in the system of "personality professional environment" and to find out how it should be optimized.; 2) since stress is generated by too high subjective assessment of the conflict situation, it is necessary to correctly identify a line of tolerant and balanced behavior to overcome the difficulties of communication; 3) since stress leads to a deregulation of the mechanisms of activity, therefore causes "re-evaluation" of personal abilities, the accumulation of chronic effects, which causes sustained pathological changes in the structure of the personality, so the question of introducing a set of training programs for the formation of skills and abilities to overcome stressful situations is worth urgent consideration. Ignoring such approaches to assessing the stress of workers can lead to their professional "burnout", and in the future - to the professional deformation of their personality.

4. Examination of the state of stress in professional activity suggests that phenomenologically and in terms of the peculiarities of regulation mechanisms, the professional stress of the employees of the National Police of Ukraine is a specific type of stress and can be defined as a multidimensional phenomenon of physiological and 
psychological reactions of the law enforcement officer to a difficult official situation.

5. The model of professional stress among National Police staff of Ukraine consists of three blocks: external stress factors; internal stress factors; physiological and psychological manifestations of professional stress.

6. Long-term effects of stress factors have a profoundly deforming effect, requiring the employees of the National Police of Ukraine to maximize physical and psycho-emotional pressure, as well as high level of professional preparedness and a high level of development of the internal imperative.

7. The empirical study made it possible to outline the specifics of occupational stress among National Police staff of Ukraine and to identify the factors such as personal adaptive index, neuropsychiatric resistance, anxiety, communicative ability, moral normativity. Also, high levels of physiological and emotional stress are empirically proven, reflecting the specifics of the influence of the professional activity of the personality of the policeman on his emotional sphere.

8. The main special psychological conditions for the training of National Police officers of Ukraine to prevent and overcome professional stress include: 1) mastering knowledge about the nature and determinants of professional stress; 2) mastering methods for identifying professional stress; 3) studying the mechanism of prevention and overcoming professional stress.

9. The complex problem of prevention and overcoming the phenomenon of professional stress by the employees of the National Police of Ukraine provides for the constant provision of psychological support through the use of interactive techniques (anti-stress programs).

\section{SUMMARY}

The article deals with theoretical and methodological analysis of stress factors that influence the employees of the National Police of Ukraine during their professional tasks execution, discusses the methodological substantiation of the experimental study of stress resistance, and reveals the main directions of the research. The determinants of stress resistance, structural components of the individual and the influence of individual and psychological properties of the individual as a subject of the activity on the ways of 
constructing behavioral strategies for stress management in risky and stressful conditions of the activity are considered. The understanding of the relations between stress resistance and the individual and psychological characteristics is analyzed. It is argued that the activities of the National Police staff of Ukraine are carried out in extremely difficult conditions, namely: an unstable political and economic situation in the state, an aggressive environment of communication, extreme and risk-taking, constant shortage of time, a high level of responsibility for the results of the activities. It is revealed that the problem of stress experience is extremely relevant, and the ability to overcome it and cope with it is transformed into a frontal problem. It is noted that the lack of psycho-emotional preparedness of the policemen leads to the poor quality of operational tasks performance, wounds, and sometimes deaths. Among a number of stress factors that negatively affect the psycho-emotional state of the police officers, the following ones are singled out: seizure of hostages by terrorists; confrontation with an armed criminal; apprehending a dangerous perpetrator; getting mutilation or injury while performing professional duties; constant interaction with criminality; a high level of responsibility for the decisions taken in conditions of information uncertainty; stressfulness and riskiness of performed duties; tension in communication in the field of professional activity; the use of measures of physical coercion or weapon for defeat. The model of professional stress of employees of the National Police of Ukraine, which consists of three blocks: external stress factors; internal stress factors, physiological and psychological manifestations of professional stress is presented. The level of professional stress among law-enforcement officers is analyzed, and three latent factors, which have a significant influence on the personality of the policeman and his reaction to stress, are distinguished. The need for anti-stress programs for the employees of the National Police of Ukraine is highlighted. It is revealed that the complex problem of prevention and overcoming of the phenomenon of professional stress of the employees of the National Police of Ukraine anticipates a usual provision of psychological support realization with the use of interactive techniques. 


\section{REFERENCES}

1. Селье Г. Стресс без дистресса. М.: Прогресс, 2005. 253 с.

2. Апчел В.Я. Стресс и стрессоустойчивость человека / В.Я. Апчел, В.Н. Цыган.

3. Овчинников Б. В., Колчев А. И. Профессиональный стресс и здоровье // Психология профессионального здоровья. СПб. : Речь, 2006. C. 204-213.

4. Abouserie R. Stress, coping strategies, and job satisfaction in university academic staff. Educational Psychology. 1996. № 16. P. 49-56.

5. Mechanic D. Students under Stress. New York: Free Press, 1962. P. 117.

6. Basowitz H., Persky H., Korchin. Sh., Grinker R. Anxiety and Stress: An Interdiscipplinary Study of a Life Situation. New York: McGrow-Hill, 1955. P. 203-243.

7. Selye H. The stress of life. New York: McGrow-Hill, 1956. P. 81-94.

8. Бодров В.А. Информационный стресс : учебное пособие. М.: ПЕРСЭ, 2000. $352 \mathrm{c}$.

9. Тімченко О.В. Синдром посттравматичних стресових порушень: концептуалізація, діагностика, корекція та прогнозування : монографія. Харків : Вид-во Ун-ту внутр. справ, 2000. 268 с.

10. Рогачова Т.В., Залевський Г.В., Левицька Т.Е. Психологія екстремальних ситуацій і станів. Т.: Видавницький дом ТГУ. 2015. $276 \mathrm{c}$.

11. Margolis B.L., Kroes W.H., Quinn R.P. Job stress: an anlisted occupational hazard. Journal of Occupational Medisine. 1974. No 6. P. 659-661.

12. Кокс Т. Стресс / Т. Кокс. М., 1981. 216 с.

13. Китаев-Смык Л. А. Психология стресса. М. : Знание. С. 340.

14. Бодров В.А. Информационный стресс : Учебное пособие для вузов. М.: ПЕРСЭ, 2000. 352 с.

15. Борневассер М. Стресс в условиях труда // Психические состояния. Хрестоматия. СПб.: Питер, 2000. С. 195-214.

16. Санникова О.П. Адаптивность личности : монография. О.П. Санникова, О.В. Кузнецова. О. : Изд. Н.П.Черкасов, 2009. 258 с.

17. Васильев В.Н. Здоровье и стресс. М.: Знание, 1991. 160 с. 
18. Пономаренко В.А. Пора прекратить избиение «человеческого фактора». Вестник МНАПЧАК. 2008. №1 (27).

19. Лебедев В.И. Личность в экстремальных условиях. М. : Политиздат, 1989. 304 с.

20. Гримак Л.П. Резервы человеческой психологии. М.: Политиздат, 1987. $231 \mathrm{c.}$

21. Синдром “професійного вигорання” та професійна кар'єра працівників освітніх організацій: гендерні аспекти : навч. посіб. для студ. вищ. навч. закл. та слухачів ін-тів післядиплом. освіти / за наук. ред. С.Д. Максименка, Л.М. Карамушки, Т.В. Зайчикової. К.: Міленіум, 2004. 264 с.

22. Averill J.R. (2005). Emotions as mediators and as products of creative activity. In J. Kaufman \& J. Baer (Eds.), Creativity across domains: Faces of the muse. (pp. 225-243). Mahwah, NJ: Erlbaum.

23. Brajt Dzh. Stress: Teorii, issledovanija, mify. SPb.: Evroznak, 2003. $352 \mathrm{~s}$.

24. Karasek R.A. Job demands, job decision latitude, and mental strain: Implications for job redesign. Admin. Sci. Q. 1979. Vol. 24. P. 285-307.

25. Хокки Р., Хамильтон П. Когнитивные паттерны стрессовых состояний // Психология труда и организационная психология: современное состояние и перспективы развития : Хрестоматия. М.: Радикс, 1995. С. 225-242.

26. Furnham A. Personality of work. London: Routledge, 1992. 354 p.

27. Ross K., Altmaier E. A. Handbook of Counseling for Street at Work. London: Sage Publication, 1999. 108 p.

28. Тімченко О.В. Професійний стрес працівників органів внутрішніх справ України (концептуалізація, прогнозування, діагностика та корекція) : автореф. дис... д-ра психол. наук: 19.00.06. Х.: НУВС, 2003. 35 c.

29. Кісіль 3.Р. Юридико-психологічні засади запобігання професійній деформації працівників правоохоронних органів : монографія. Львів: Львівський державний університет внутрішніх справ, 2016. 848 с.

30. Осьодло В.I. Особистісні чинники подолання стресових ситуацій в особливих умовах. Проблеми екстремальної та кризової психологї̈. 2013. Вип. 14(1). С. 242-252. 
31. Барко B.I. Психологія управління персоналом органів внутрішніх справ (проактивний підхід) : монографія. К.: НікаЦентр, 2003. 448 c.

32. Лєфтєров В.О. Теоретичний аналіз стресогенних чинників професійної діяльності працівників міліції. Вісник Національної академії оборони. № 4(17). 2010. С. 167-171.

Information about the author: Kisil Z. R.

Doctor of Law Sciences, Professor, Academician of the HEAS of Ukraine, Dean of Faculty No. 7 , Lviv State University of Internal Affairs 